Article

\title{
The Integration of RoRo Shipping in Sustainable Intermodal Transport Chains: The Case of a North European RoRo Service
}

\author{
Anastasia Christodoulou*(D), Zeeshan Raza and Johan Woxenius $\mathbb{D}$ \\ Department of Business Administration, University of Gothenburg, 40530 Gothenburg, Sweden; \\ zeeshan.raza@handels.gu.se (Z.R.); johan.woxenius@gu.se (J.W.) \\ * Correspondence: anastasia.christodoulou@gu.se; Tel.: +46-31-786-6437
}

Received: 23 February 2019; Accepted: 30 March 2019; Published: 24 April 2019

\begin{abstract}
Roll on-roll off (RoRo) shipping represents a maritime segment that could easily form part of an intermodal transport system, as cargo does not need to be lifted in ports; it is 'rolled' to and from sea. This paper investigates the operation of RoRo shipping services in Northern Europe, focusing on a set of services chartered by a major shipper whose demand has a great impact on the service design, potentially affecting the frequency of departures and even stipulating the use of specific vessels. The case of cooperation between Stora Enso, a major forest company in Sweden and Finland, and the shipping company Swedish Orient Line (SOL) is analysed, giving some insight into the way these RoRo services operate and manage to integrate successfully into sustainable intermodal transport chains. Despite various initiatives taken by different stakeholders, the level of integration of shipping in intermodal transport chains has been quite slow. This paper's results could contribute to the identification of barriers that prevent RoRo shipping from being a viable alternative to road transport for certain transport routes and assist in the discovery of policies and incentives that could lead to developing sustainable intermodal transport chains.
\end{abstract}

Keywords: RoRo shipping; intermodal transport; Northern Europe; forest industry

\section{Introduction}

Sea transport offers significant environmental advantages, as it transfers more than $90 \%$ of the global trade in volume while emitting around 2.2\% of total global greenhouse gas emissions [1]. In 2015, maritime transport, including domestic and international shipping, emitted 151 million tonnes of $\mathrm{CO}_{2}$ equivalents in the 28 European member states, accounting for $12.7 \%$ of the transport sector's total emissions [2]. However, integration of shipping into intermodal transport chains has not been achieved until now, despite various initiatives undertaken by stakeholders [3]. Significant differences amongst diverse segments of the shipping industry need to be considered for adoption of effective policies and incentives that could lead to further use of shipping in intermodal transport chains [4]. Roll on-roll off (RoRo) shipping represents a maritime segment that could easily form part of an intermodal transport system, as cargo does not need to be lifted in ports; it is 'rolled' to and from sea. However, the employment of RoRo shipping depends on several parameters, such as the type of cargo transferred and cargo volumes, and is strongly influenced by shippers' demands that 'define' its operations. RoRo shipping, in contrast to deep sea segments, faces strong competition from land-based modes of transport and constantly seeks to satisfy shippers' demands and offer high-quality transport services [5].

Although the development of maritime supply chains has been investigated extensively in the supply-chain management literature, limited focus has been given to the potentially different barriers 
that prevent different maritime segments from being part of intermodal transport chains [4,6-9]. It is exactly this scientific gap that this study addresses: the need to consider various maritime segments separately and research their potential to form part of intermodal supply chains and support sustainable transport operations. This paper aims to investigate how maritime transport and, in particular, RoRo shipping can be integrated into intermodal transport chains and highlight the potential environmental benefits from such an integration. A novel aspect of this research is that it takes into consideration the particular features of RoRo shipping and how they enable or prevent this maritime segment from being included in intermodal supply chains.

This paper explores the operation of RoRo shipping services in Northern Europe, focusing on a set of services chartered by a major shipper whose demand has a significant impact on service design, potentially affecting the frequency of departures and even stipulating the use of specific vessels. The geographical area of Northern Europe was chosen in our study, due to the extensive use of RoRo services in this region as well as the development of innovative business models for the satisfaction of the transport needs of major shippers, belonging to the automotive, forestry, food and drinks, and electric equipment industries.

The case of cooperation between Stora Enso, a major forest company in Sweden and Finland, and the shipping company Swedish Orient Line (SOL) is analysed, giving some insight into the way these RoRo services operate and manage to integrate successfully into sustainable intermodal transport chains. Stora Enso has developed a unique intermodal logistics system for the transport of its products using an innovative cargo unit, the Stora Enso Cargo Unit (SECU), which can be transported by ships and trains in Sweden and Finland. The hub of the logistics system is the port of Zeebrügge, but the Port of Gothenburg plays an important role for the Swedish flows as the SECUs are transhipped to RoRo vessels from the railway to reach continental Europe.

This paper's results could contribute to the identification of barriers that prevent RoRo shipping from being a viable alternative to road transport for certain transport routes and assist in the discovery of policies and incentives that could lead to the development of sustainable intermodal transport chains. The paper is structured in the following way: Section 2 describes the existing literature on intermodal and RoRo shipping operations and reviews the employment of RoRo services by the Nordic forest industry. In Section 3, the case study methodology used in our analysis is presented, while the case study of a Swedish RoRo shipping company cooperating with a major Swedish-Finnish forest company is analysed in Section 4. The significant findings of the paper, as well as our main conclusions, are summarised in Section 5.

\section{RoRo Shipping}

This section includes a brief presentation and analysis of the literature on intermodal transport and RoRo shipping, focusing on Northern Europe's RoRo services and coming to the employment of RoRo shipping by forest companies.

\subsection{Literature on Intermodal Freight Transport and RoRo Shipping}

Intermodal transport consists of the combination of at least two traffic modes for the transfer of freight and is considered to offer a more sustainable transport service compared to unimodal systems, due to the aggregated benefits of each single mode [10]. Given the growth of global trade and the increased transport volumes, intermodal transport can enable a shift from road to more sustainable traffic modes, such as rail, sea or inland waterways and reduce the external costs from these transport services, including air pollution and congestion as well as accident events [11]. However, the development of intermodal transport chains is more complex than unimodal systems, as it implies the integration of different stakeholders and decision-makers that need to collaborate to ensure the efficient operations of the intermodal system $[6,7,10,12]$. Recent literature has focused on the various constraints that have a negative impact on the development and operations of intermodal logistics chains and prevent their further development [13]. Pricing problems in intermodal freight transport 
are highlighted by Tawfik and Limbourg [14]. According to their findings, certain intermodal operators choose to set the prices of their transport services on the basis of profit maximisation, even though they can predict the possible reaction of their shippers to choose a road alternative.

Special attention has been given to the integration of shipping in intermodal transport chains during the last decades [3]. Apart from its environmental performance, maritime transport has unlimited capacity and does not require high infrastructure investments, as compared to rail [15]. Maritime transport is divided into various segments that present substantial differences in their operations as well as their market structure [5]. RoRo shipping is largely differentiated from the other maritime segments due to its elasticity of demand that is much higher than the other segments, as it faces strong competition from land-based modes of transport. In general, RoRo services are liner services where frequent, scheduled seaborne transport services are offered between predestined ports of call. RoRo vessels are characterised as horizontally loading vessels, as their cargo can be towed into the vessel or brought in on wheeled vehicles without any special equipment, in contrast to LoLo (lift on/lift off), where the cargo needs to be loaded and uploaded by cranes $[8,16]$.

According to Medda and Trujillo [17], RoRo vessels represent one of the main categories of the short sea shipping (SSS) market and are amongst "the most innovative shipping technologies from which we can effectively determine competitive SSS operations", as the horizontal handling of RoRo units implies low transhipment costs and fast cargo handling, essential for enhancing the competitiveness of SSS. Douet and Cappuccilli [18] outline the potential that RoRo shipping offers a modal shift in Europe due to the existence of road hauliers that (could) act as customers of the intermodal transport chain. However, RoRo operations require large cargo volumes and high frequency of departures to be economically feasible due to the initial capital cost of these vessels, which is significantly higher than a container feeder vessel of equivalent size [19]. Zachcial [9] also mentions the high construction and operational cost of RoRo vessels-due to their inevitably lower load factor compared with containerships" - as a possible explanation for their "limited" employment in Europe. In addition to the economic parameter, he points out the need for a 'cultural' change from the sides of both shipowners and shippers for the development of efficient RoRo logistics operations that require different working methods, where inland and maritime carriers' operations are complementary rather than competitive. $\mathrm{Ng}$ et al. [3] underline the importance of ports for the establishment and successful operation of intermodal RoRo services, mentioning the high cost of cargo handling in ports that can significantly reduce their competitiveness and feasibility. Apart from port costs, extended times in ports can negatively influence the competitiveness of intermodal RoRo services [20]. Port interfaces, transit time and extra cargo handling costs were also identified as some of the main challenges for the development of short sea shipping in Canada [21]. According to Konstantinus et al. [22], considering the importance of synergies, effective policies are necessary to support SSS, developing cooperation among the transport chain members and improving the trust between them.

The sustainability aspects of RoRo and Roll on-Roll off Passenger (RoPax) shipping operations were highlighted by López-Navarro [23], who used the external cost calculator for Marco Polo freight transport project proposals in order to compare the environmental performance of road haulage and SSS. The Marco Polo calculator coefficients consider air pollution and climate change in SSS, are measured in euros per ton-kilometre and depend on the speed the RoRo/RoPax vessels operate at as well as the type of fuel they use. The RoRo vessels examined in this study operate at 15 knots and use low-sulphur fuel. This means that, according to Marco Polo calculator coefficients, the external cost of these vessels' operations is 0.0045 euros per ton-kilometre, compared to road transport that accounts for 0.0185 euros per ton-kilometre. Medda and Trujillo [17] and Paixão and Marlow [24] mentioned the reduced fuel consumption and related emissions of SSS compared to road and rail transport. This fact is verified by recent European transport statistics, where SSS accounts for 1\% of the energy consumption and $12.1 \%$ of the emissions related to the European transport sector, while transferring $32 \%$ of the total freight volumes [25]. Nevertheless, the sustainability performance of RoRo shipping was strongly questioned by Hjelle [26], who pointed out that the low load factor of RoRo/RoPax vessels in addition 
to high operating speeds can result in high energy consumption and related emissions, suggesting road transport as the most environmental-friendly alternative. According to Hjelle [26], RoRo shipping represents the greenest transport alternative only in the case that NOx abatement technologies and low-sulphur fuels are used, operational speed is low and the utilisation rate of the RoRo service is high.

\subsection{RoRo Shipping Segments}

RoRo shipping is further divided into four submarkets: (a) the deep sea car carrying trade that includes the seaborne vehicle trade all over the world and is transported mainly by Pure Car and Truck Carriers, (b) the deep sea liner trade with RoRo facilities that combines the transport of containers and RoRo cargo on the same ship and is usually called the 'ConRo' (container-RoRo) submarket, (c) the shortsea RoPax ferries for the transport of both passengers and freight and (d) the shortsea unaccompanied freight (only) transport submarket [27]. The shortsea RoRo shipping segment (RoPax and unaccompanied RoRo) plays a significant role in the European seaborne trade, accounting for $14 \%$ of the total SSS of goods to and from main European Union ports in 2015 (Figure 1).

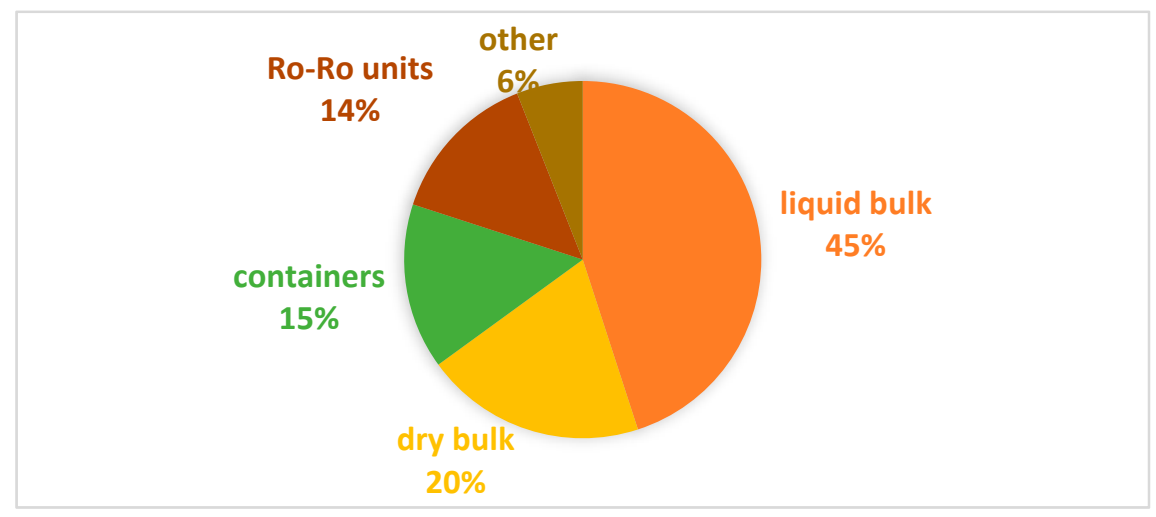

Figure 1. Short sea shipping of goods by type of cargo in the European Union in 2015 (\% gross weight of goods). Source: Own elaboration based on data from Eurostat [28].

The integration of SSS in European intermodal transport chains has been an issue of major concern during the last decades, as it represents an environmentally friendly, energy-efficient and safe alternative to road transport that can facilitate the connection of remote and peripheral regions without requiring high infrastructure investments [15]. Sufficient cooperation with other modes of transport, low port costs and simplification of administrative and documentation procedures in ports are crucial factors for the further employment of SSS in intermodal logistics chains [3]. According to Paixão Casaca and Marlow [29], the improved efficiency of the carrier's transport network and the adoption of a different management approach that relies on carrier-shippers' relationships could enable the integration of SSS into multimodal transport chains.

This paper focuses on the operations of the fourth submarket of RoRo shipping, unaccompanied freight transport, which is largely employed by the forest-products companies in Northern Europe for the export of their products. Vessels involved in the unaccompanied freight RoRo submarket are old, rather large vessels that share the limitation of carrying up to 12 drivers [27]. López-Navarro et al. [30] mention that unaccompanied freight transport requires a quite complex organisation and is often chosen by large companies that handle high cargo volumes, as it implies major operational and organisational changes. These changes are related to five key operational areas: organisation of haulage and fleet restructuring, restructuring of driving staff, changes in the operating model and development of coordination capabilities, improving the commercial capacity at the destination, and establishing an adequate infrastructure to organise haulage in the destination country [31].

According to Eurostat [28], in 2015, 184 million tons of unaccompanied freight RoRo units were handled in main European Union ports, with the United Kingdom having by far the largest cargo 
volume of 51 million tons, followed by Italy, Belgium, Sweden and Germany. At port level, Immingham, Rotterdam, London and Gothenburg are major ports for the transport of mobile non-self-propelled RoRo units. In the next section, we focus on shortsea unaccompanied freight RoRo services in Scandinavia and the North Sea, which represents the major areas of these RoRo vessels' operations.

\subsection{RoRo Shipping in Northern Europe}

Unaccompanied RoRo services are widely used in Northern Europe to satisfy the transport needs of the automotive, forestry and electric equipment industries as well as imports of food and drinks. A large share of the shortsea RoRo traffic is located in the North Sea, linking Scandinavia, the UK and continental European ports and accounting for about 38\% of the total European RoRo market [28]. The existence of this type of cargo, in addition to the topography of Northern Europe, consisting of countries with long coastlines and industrial and production centres near the coast, favour the use of RoRo shipping in relation to other maritime segments and land-based modes of transport [24]. Moreover, adequate cargo volumes in Scandinavia and the North Sea guarantee high frequency of departures for shippers and high-capacity utilisation for the shipping companies, which are both vital for the economic feasibility of the RoRo services [32]. According to Ng [33], "reasonable frequency, regularity and interoperability between land and maritime components" represent key factors for the competitiveness of SSS.

RoRo shipping holds a substantial share of the total cargo handled in the main ports of Northern Europe [28]. Finland and Sweden are amongst countries where this maritime segment plays a predominant role in freight transport, representing almost one-fifth of the total cargo handled in Finnish ports and more than one-quarter of the cargo handled in Swedish ports.

The transport demand of the Swedish automotive and forestry industries occupies the largest volume of short sea RoRo operations and determines the services provided. Both industries are characterised by the existence of a few large companies that need to transfer large volumes of cargo and often charter RoRo vessels to transport their goods. The unaccompanied freight transport RoRo shipping segment in Scandinavia is operated by a few shipping lines, such as Transfennica, employing 12 ice-strengthened RoRo vessels between Finland and major European ports; DFDS, with 21 RoRo vessels operating in the North and Baltic Sea; Finnlines, operating 21 RoRo vessels in the North and Baltic Sea; and SOL, with eight RoRo vessels (company websites). Many of these RoRo services are contracted for long periods by forestry companies that 'guarantee' the baseload.

\subsection{RoRo Shipping and the Nordic Forest Industry}

The forest industry is one of the most important business sectors in Sweden and plays a vital role in the country's economy, accounting for $9-12 \%$ of the employment, exports, turnover and added value in Swedish industry [34]. As can be seen in Figure 2, the forest industry is the sixth-largest exporting sector in Sweden, following engineering products, electronic goods and the automotive industry. Note the large net export value in comparison with the automotive industry. The situation is quite the same for Finland, where forestry is the second-largest Finnish industry, accounting for 20.3 billion euros in 2016 (Figure 3). 


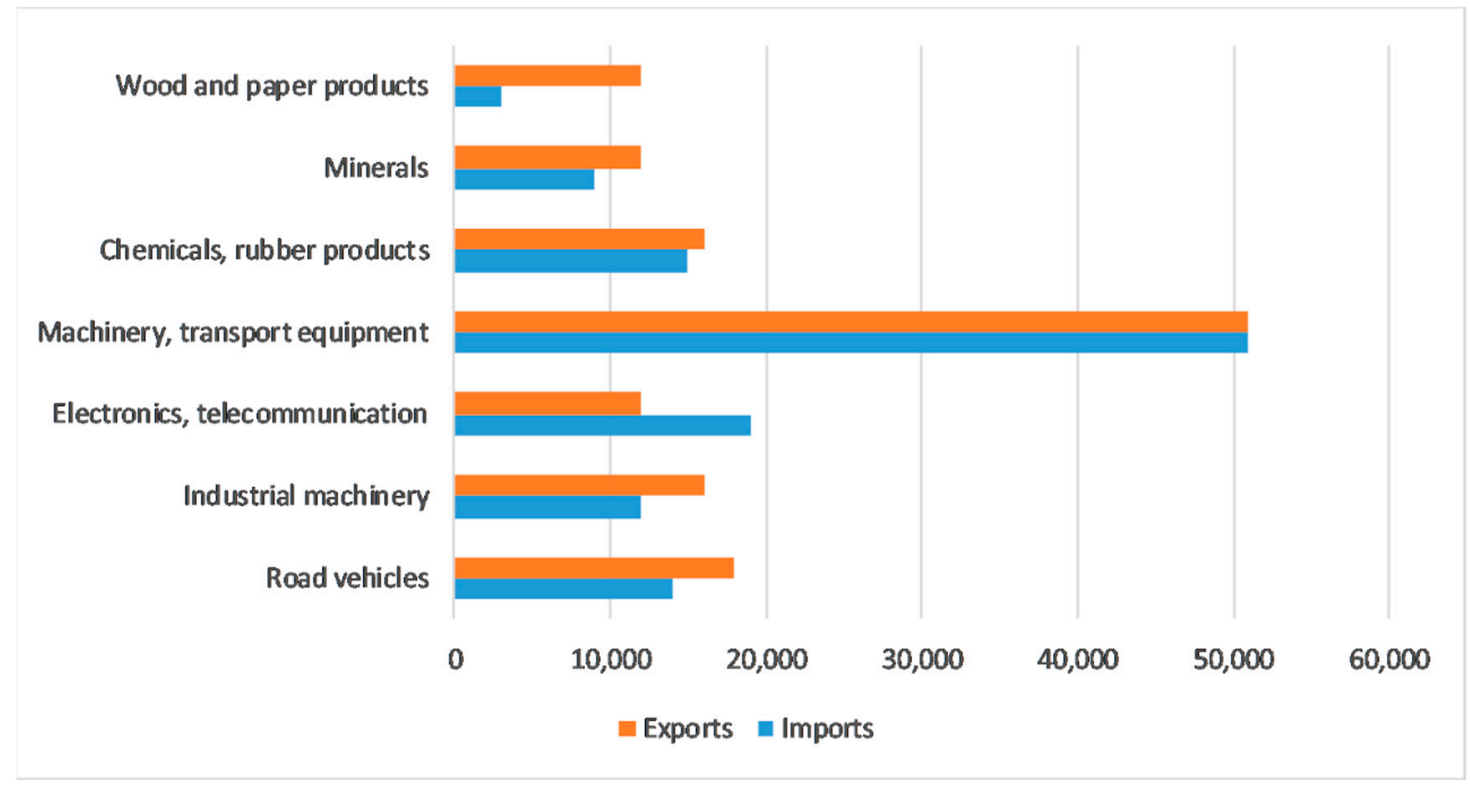

Figure 2. Swedish imports and exports in product groups (in million Swedish Kronas (SEK)— 100 k€) in 2017. Source: Own elaboration based on data from Statistics Sweden.

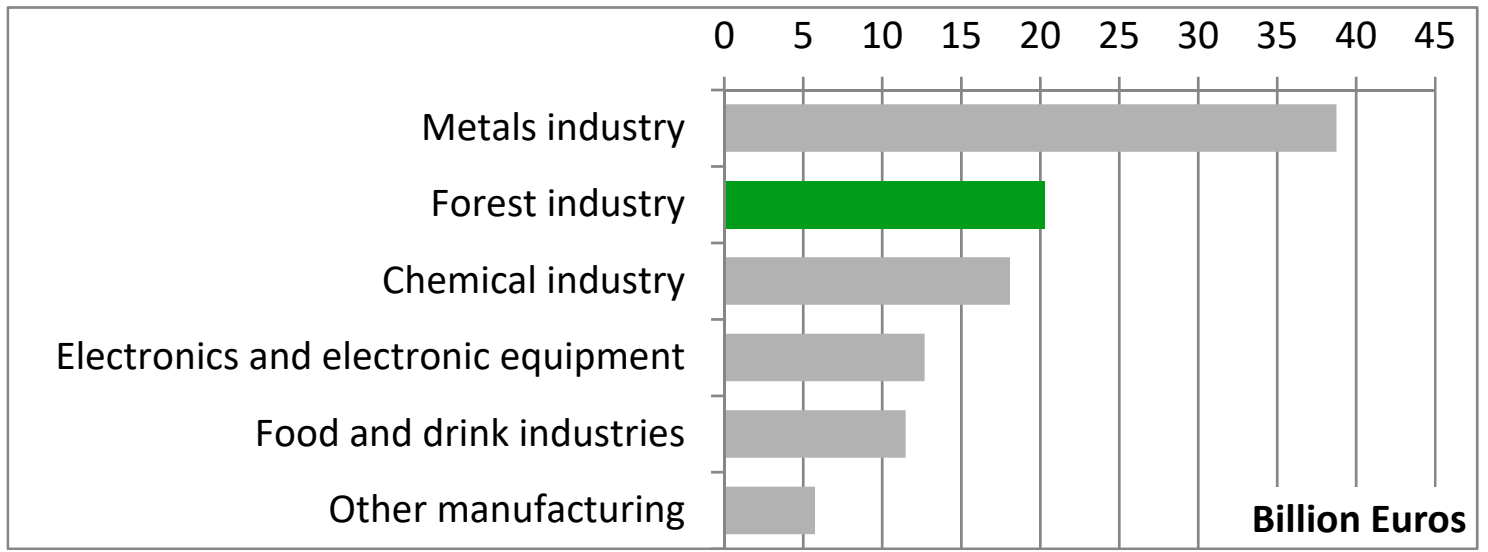

Figure 3. Annual turnover of the largest industries in Finland (in billion $€$ ) in 2016. Source: Own elaboration based on data from the Finnish Forest Industries Federation.

In 2016, 11.6 million tonnes of pulp, 10.1 million tonnes of paper and 17.8 million cubic metres of sawn timber were produced, making Sweden the world's third-largest exporter of these products [34]. As the Swedish forest industry is strongly export-oriented- $80 \%$ of the forest products are exported-and the transport of large volumes of products is required, it represents Sweden's largest purchaser of transport services, accounting for SEK 25 billion ( 2.5 billion $€$ ) annually. It is characterised by a small number of large companies-such as SCA, Stora Enso, Holmen and BillerudKorsnäs-that have developed their own intermodal transport systems which combine railways, RoRo vessels and road transport. These systems provide them with a sort of flexibility and secure capacity for the satisfaction of their transport needs.

The forestry industry is the business sector that utilises Sweden's railways the most, accounting for one-quarter of all rail freight transport [35], but shipping is employed for exporting the largest part of the Swedish forest products. As much as $61 \%$ of pulp and paper is exported by sea, while this percentage reaches $57 \%$ for sawn timber (Figure 4 ). 

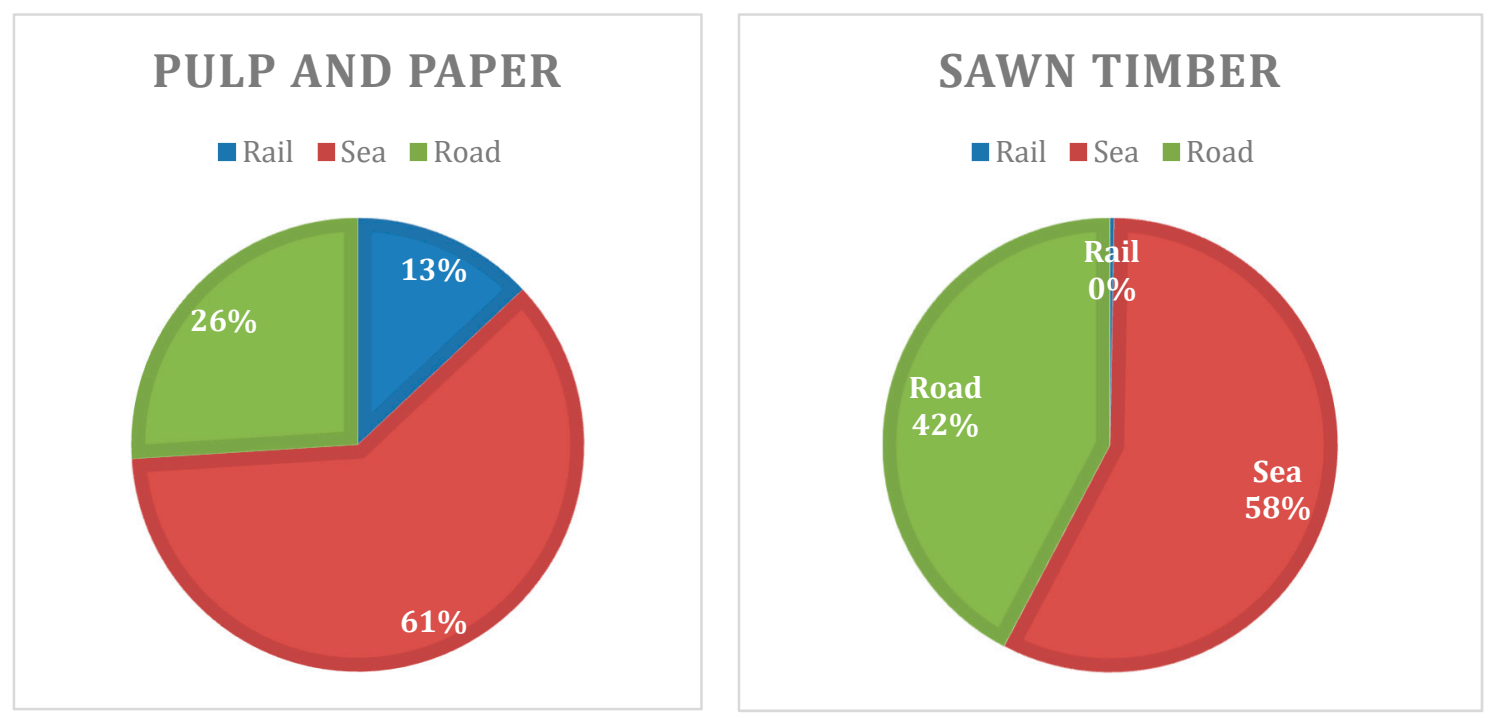

Figure 4. Modes of transport for the export of Swedish pulp and paper in 2016 (in million tonnes) Swedish sawn timber in 2016 (in million tonnes) Source: Own elaboration based on data from the Swedish Forest Industries Federation.

The Port of Gothenburg is the largest forest port in Sweden, playing a key role and serving as a freight hub for the export of forest products [35]. The Port of Gothenburg offers a wide range of services and destinations, with 80 RoRo and 20 container ship departures each week to a range of destinations in the UK and on the European continent. The port has three RoRo terminals specialising in European traffic, operated by Gothenburg Roro Terminal, Stena Line and Logent Ports \& Terminals, where all types of unitised rolling goods, as well as containers and goods loaded onto cassettes, are transhipped. The RoRo terminals are also linked to the rail system, with tracks running directly to the quayside, enabling intermodal transport of forest products. The fact that around 70 trains arrive and depart from the port each day gives some insight into the large cargo volumes handled in the port and integrated into an intermodal logistics system.

\section{Methodology}

The previous sections showed that RoRo shipping can offer an environmentally friendly and cost-efficient option to meet the transport needs of various industries. A contemporary phenomenon or event, which cannot be explored beyond its context, is better investigated through a case study approach [36,37]. To discover and understand the real-life phenomenon of successfully integrating SSS into intermodal transport chain on certain routes, an in-depth case study was conducted, highlighting the main drivers (enablers) that enhance SSS integration within the intermodal transport chain from a large shipper's perspective.

Eisenhardt [38] emphasises that in case study research, sample selection should be tightly aligned with the purpose of the research. This paper focuses on a RoRo service designed and operated by Stora Enso in cooperation with SOL for transporting its own as well as external parties' cargo. Voss, Tsikriktsis and Frohlich [36] recommend interviewing more than one respondent in situations where a single respondent does not have all required knowledge of the phenomenon, or where different interpretations of a phenomenon are expected. Thus, to overcome subjectivity and bias issues and enhance the reliability of our data, we conducted one semi-structured interview with Stora Enso (a forest-product shipper and vessel charterer) and a second semi-structured interview with SOL (a ship management and forwarding agent that collaborates with Stora Enso).

Input from the shipping line, the major shipper and another user of the RoRo service enhances the perspective of this article to study the case of integrating sustainable RoRo shipping services into intermodal transport chains. The interview with the major shipper Stora Enso aims at identifying the 
way RoRo is successfully integrated into its intermodal transport system and the way this transport system works in practice. The interview with the shipping company verifies these findings and gives some additional data on the types of cooperation amongst the two parties (shipper and carrier). In addition, an interview with a forwarding company, France Sped, which uses the shipping service, confirms and reflects on some statements by the two main actors.

A crucial step in this research was identifying appropriate respondents from each company with deep knowledge of their logistics needs and practices. From Stora Enso, Kristian Kisch, the manager of European shipping services, was identified as the main interviewee [39], and an additional interview was done with Knut Hansen, senior vice president of Stora Enso and Chief Executive Officer of Stora Enso Logistics AB since 2008 [40]; the interview mainly focused on an ongoing labour market conflict in the Port of Gothenburg. Furthermore, a telephone interview was conducted with Stig Wiklund, who was employed in managerial positions by Stora/Stora Enso from 1985 to 2012 and then assumed a role of senior advisor until 2016 [41]. Another interview was conducted with Henrik Kappelin, network design and transport analyst for Stora Enso, involved in route/supply chain optimisation based on cost, service level and sustainability criteria [42]. The second main respondent, Ragnar Johansson, is the managing director of SOL [43]. As a representative of the third-party users of the service, Kristina Bengtsson, CEO of France Sped, was also interviewed [44].

Interviewees were chosen based on their positions and experience. As the main respondent from Stora Enso, Kisch holds a strategic position in the company's sea freight transport system and is knowledgeable in the way this system operates and manages to satisfy the company's transportation needs in a sustainable way combining three traffic modes (rail, RoRo shipping and road). Hansen assisted in understanding Stora Enso's current priorities, and Wiklund, who served in various positions including interim vice president, business development of Stora Enso Logistics from 2008 to 2012 and acting CEO from 2007 to 2008, helped capture the history of Stora Enso's logistics development and verify the statements from the other two Stora Enso respondents. He also contributed by putting the development into a proper strategic context. Kappelin provided valuable input on Stora Enso's current supply-chain network design, based on liaising with land and sea procurement categories to improve and facilitate transport supplier negotiations. At SOL, Johansson is responsible for sustainable operations of the RoRo vessels employed by Stora Enso and provided valuable input into the way the two companies cooperate and manage to generate additional environmental and financial benefits. The CEO of France Sped contributed with valuable insights from a smaller user of the service as it is marketed in the open freight market. We sent the interview protocols to the respondents in advance, as this might have helped them collect their thoughts. The interviews lasted 60 [39], 75 [40], 30 [41], 45 [43], and 30 [44] minutes, respectively, and the interviews were audiotaped and later transcribed. Email correspondence was used for the interview with Kappelin. For additional data, benefitting from a triangulation technique [37], we used respondent companies' websites, external reports and newsletters. Furthermore, a few less-detailed interviews were carried out with personnel from the case companies. The manuscript was sent to all respondents to verify the facts and citations used.

The research design does not allow for generalising the findings on the development of sustainable RoRo operations and their integration into intermodal transport chains due to the rather limited number of interviewees. The focus is on the dominant shipper of the RoRo service, but a third-party user of this service is also interviewed. Further research is needed to support the findings. Additionally, only one case study of shipper-carrier cooperation is analysed in this research. It cannot be considered as representative of transport practices in general, as the main shipper demonstrates a high commitment to sustainable transport procurement, and the carrier operates in Northern Europe, where high sustainability requirements in sea freight transport are applied. The results are likely to be different in other industrial segments or geographical regions of the world. Nevertheless, the successful integration of RoRo shipping in the intermodal transport systems of Stora Enso and SOL is worth investigating due to the valuable, practical input it offers and the identification of potential environmental and financial benefits from such integration. 


\section{Results}

The results of the case study are presented in this section.

\subsection{Stora Enso}

Stora Enso was formed through a merger between the Swedish forest company Stora and its Finnish competitor Enso in 1998. It produces paper and packaging products, biomaterials and wooden constructions and provides them all over the world. The company employs around 26,000 people in more than 30 countries. In 2018, Stora Enso had a turnover of 10.5 billion $€$, while its operational earnings before interests and taxes (EBIT) reached 1.36 billion $€$ [45]. Most of the company's sales and operations take place in Europe, with Germany and Sweden being the biggest markets for the company's production in Europe.

Stora Enso makes extensive use of sea transport, which accounts for approximately $89 \%$ of the transport work, while road and rail transport constitute $9 \%$ and $2 \%$, respectively [46]. According to Kappelin [42] at Stora Enso, many factors influence the company's choice of transport mode. Nevertheless, cost and capacity play a crucial role, and after that, the others are considered. Stora Enso has developed a unique intermodal transport system based on SECUs transported by ships and trains; the latter, however, only in Sweden and Finland with generous loading gauges. SECUs are large intermodal containers, similar to standard 40-foot containers but bigger, with dimensions $13.8 \times 3.6 \times 3.6 \mathrm{~m}$ and a cargo capacity of 80 tonnes compared to the (International Organization for Standardization) ISO container's 26.5 tonnes. Stora developed the SECUs before its merger with the Enso, but they were implemented after the merger in 1998 [41] after a decade of 8-10\% annual volume growth and with high expectations for further growth. According to Georgopoulou et al. [47], SECUs are included in baseline green technologies for the establishment of green corridors and are categorised as innovative units for multimodal transport. However, moving SECUs onto ships and rail wagons requires special translifters. This equipment can be found mainly in ports in major production and consumer countries for Stora Enso, such as Finland (Kotka and Oulu), Sweden (Gothenburg), Belgium (Zeebrügge), the UK (Tilbury, Immingham) and Germany (Lübeck). These areas form the backbone of Stora Enso's SSS network.

\subsection{Stora Enso's Short Sea Network of Services}

According to Kristian Kisch [39], the company has established an SSS network of services to satisfy its transport needs, from the production units to customers (Figure 5). Production units and customers' locations are shown by the circles, while different coloured lines represent the different short sea shipping services offered by the company. Wiklund [41] states that Stora experienced strong dependence on German State Railways (DB) in its export to continental Europe that crossed German soil at a time of national rail monopolies. After the fall of the Berlin Wall in 1989, east-west flows increased and DB put less emphasis on competitive north-south services. Stora then decided to find an option to circumvent the problems in Germany by using RoRo to Zeebrügge. As rail is used to distribute goods from the port to customers in continental Europe, the customers are not affected by Stora's decision to use direct rail or maritime transport for a transport leg [41]. 


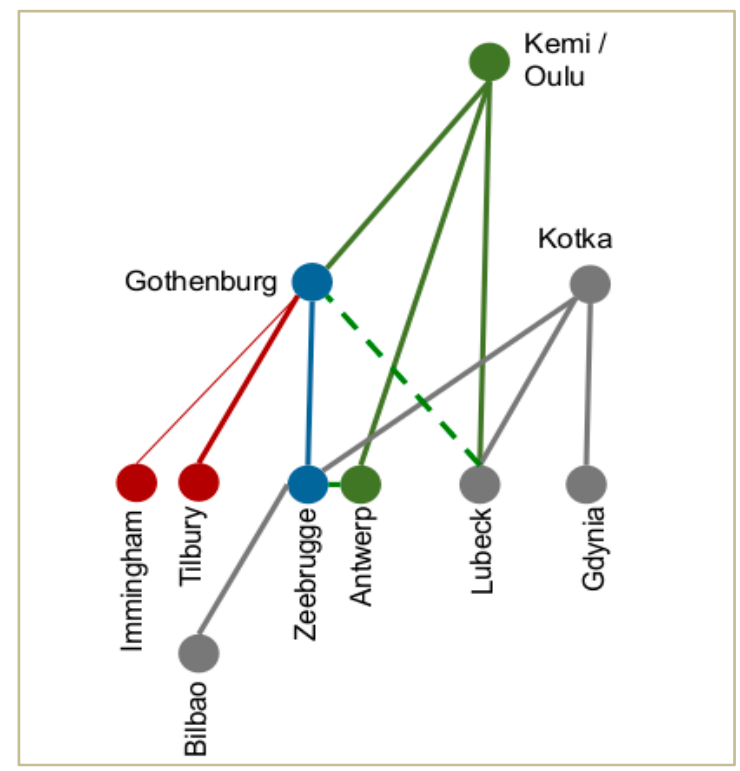

Figure 5. Stora Enso short sea shipping network. Source: Material obtained at the interview with Kisch [39] from Stora Enso.

The operation of these services presents great differentiations depending on cargo capacity, competition and market condition. Kisch mentioned that ship ownership or operation management are not Stora Enso's main function. The company chooses to charter vessels instead of owning them, maintaining flexibility to release them in the event of production pattern changes or reduced production volumes.

Kisch provided a comprehensive picture of the company's SSS network. He stated that until 2009, the company itself managed and operated the eight RoRo vessels engaged in the SSS transport system. According to Wiklund [41], it was partly a strategic decision for the company not to actively operate ships itself, partly a lack of nautical competence and partly because it wanted to implement a larger system requiring third-party goods for reasonable frequencies. Three vessels were employed on the Gothenburg-Zeebrügge route, three vessels on the north Finland routes from Kemi/Oulo and two on the south Finland routes from Kotka. However, in 2009, the company outsourced the vessels' operations and selected SOL for ship operation management of its short sea system. According to Ragnar Johansson, CEO and interviewee from SOL, SOL set up a new company, called SOL North Europe Services (SNES), which is a single-purpose company working for Stora Enso. Johansson emphasised that since then, SNES has been Stora Enso's shipping department that acts exclusively on behalf of Stora Enso as the long-term charterer of the vessels [43]:

SNES is responsible for the operation and maintenance of the vessels, the instruction of captains on board, the scheduling and booking of Stora Enso's cargo to their contracted shippers.

Kisch pointed out that at the same time, Stora Enso was selling some freight capacity, either empty space on board or empty space in the northbound SECUs, to third parties on all routes of the SSS network and had long-term contracts with other shipping companies offering these third-party services. In 2014, those contracts ended and Stora Enso began its cooperation with SOL on third-party services on the Gothenburg-Zeebrügge route. Kisch emphasised that in the same year, Stora Enso restructured its short sea transport network and changed the hub of its logistics system, replacing the Port of Gothenburg with the port of Zeebrügge in Belgium and shifting about 1.5 million tonnes of cargo per year [48]. According to Knut Hansen [40], the RoRo terminal at the Port of Gothenburg struggled and still struggles with too-high costs and unreliable service. This was confirmed in the interview with Wiklund [41]. After the shift to Zeebrügge as a hub, cargo from paper mills in Kemi 
and Oulu in Northern Finland was transferred directly to Zeebrügge, increasing the logistics system's efficiency. As Johansson [43] stated:

Then North Finland vessels did not need to come to Gothenburg as they moved to Zeebrïgge. It was a big change that saved a lot of money and increased efficiency in the system.

Both interviewees mentioned, though, that the Port of Gothenburg still plays an important role in the flow from Stora Enso's four mills in Sweden, all located rather far from the coast. Stora Enso's cargo from Southern Finland is transferred directly to Poland, Germany and Belgium by the shipping company Finnlines, as before.

According to both interviewees, since 2015, Stora Enso has cooperated with SOL not only for ship operation management, but also for selling the remaining freight capacity to external customers, either empty space on board or empty space in the northbound SECUs. Under this scheme, SOL has the responsibility for third-party sales and gets a commission, but Stora Enso charters the vessels and carries the full commercial risk of utilising the vessels. As Johansson [43] emphasised:

Then SOL took responsibility for third-party sales and got the commission, but SOL did not charter the vessels, and Stora Enso had 100\% risk of the vessels.

Kisch highlighted the two cooperation types of Stora Enso with SOL. The first type of cooperation concerns SNES' operation management of vessels on behalf of Stora Enso, while the second type of cooperation is related to SOL selling the excess freight capacity to third-party shippers [39]:

When it comes to cooperation with SOL, we have two such cooperation types... SNES operates the line and SOL is just selling like sales agents. SNES is preparing schedules, instructing captains on board, maintenance and so on, but they ask Stora Enso for confirmations. SOL's continent line is just marketing, and it's important for us to keep these two firms separate so we can scale up and down in each sailing. For managing the line, they get a management fee.

Kisch from Stora Enso also stated that the entire service around third-party freight capacity was developed considering the needs of road haulage firms and rail operators. Large external customers on the Gothenburg-Zeebrügge route are LKW Walter, NTG Transport, DSV Global Transport and Logistics, and other freight forwarders that occupy the empty space on board loading semitrailers, while Hoyer Group and Bertschi fill the empty space in the SECUs. A smaller user of the SOL-Stora Enso service is France Sped, a comparatively small forwarder operating 30 semitrailers for part-load transport services between Sweden and France. According to CEO Kristina Bengtsson [44], France Sped uses the SOL-Stora Enso Gothenburg-Zeebrügge route in the same way as it uses Cobelfret's service on the same route and DFDS on the Gothenburg-Ghent route. In all, they buy maritime transport of some 1500 semitrailers annually, deliberately distributed between the three shipping lines to foster competition [44].

According to Johansson, both Stora Enso's and other customers' cargo is allocated in each sailing depending on the agreed capacity and current demand. France Sped has a fixed allotment, but notifies SOL of the specific need for capacity on the day of departure [44]. SOL reserves an agreed capacity for Stora Enso and is not obliged to transport volumes above that level, but Stora Enso stores SECUs in Gothenburg to fill up empty capacity in a standby consignment scheme. Johansson revealed that priority is usually given to third-party forwarders so as to not to risk losing these external customers:

Well, we have agreed capacity for Stora Enso also. For instance, we are obliged to transport Gothenburg-Zeebrïgge route 260 SECUs per week, anything above that level we don't need to take it. Otherwise, we can lose DHL or LKW Walter etc., so we prefer third-party forwarders.

Bengtsson [44] confirmed that France Sped had not experienced Stora Enso having priority amongst users. Johansson added that when Stora Enso needs extra capacity to satisfy its customers' needs, it often moves a vessel from North Finland to Gothenburg despite the additional transport cost. 
According to Kisch [39], this commercial cooperation developed quickly, and in 2017, SOL sold RoRo services for nearly 100,000 third-party units on the Gothenburg-Zeebrügge route, with the utilisation rate for RoRo operations in both directions reaching about $95 \%$. This high utilisation rate is crucial for developing sustainable RoRo services, as it implies reduced fuel consumption and related emissions per unit of transport work. The company reaches such a high utilisation rate due to the flexibility of its operations. As Kisch [39] pointed out:

On Mondays, we ship more SECUs, and on Tuesdays more semitrailers, etc. If there is an accident in the port, we have standby SECUs, and at the same time if there are late bookings. We are flexible, as the final load plan is made half an hour before the vessels depart, and that's why we have such a high utilisation.

Another beneficial outcome from this commercial cooperation was the expansion of Stora Enso's SSS network and the shipment of larger volumes on its chartered vessels. As Kisch [39] stated:

Further, SOL helped us expand our network with other partners and increase the cargo volume for our chartered vessels. So we have cooperation with PEO in the North and Mediterranean Seas and SOL in Scandinavian regions.

\subsection{The SECU Rail System}

Stora Enso's mills in Sweden are located inland and connected via the SECU rail system to the Port of Gothenburg, where the cargo is transhipped to RoRo vessels. The trains involved are owned and operated by the state-owned rail operator Green Cargo. Stora Enso has certain control of the 190 wagons deployed in its system, although Green Cargo owns them. Three trains arrive daily in the Port of Gothenburg. As Kappelin [42] pointed out, the company makes extensive use of rail due to the higher loading capacity that makes it more cost efficient compared to trucks. Johansson [43] emphasised that the close cooperation with Stora Enso enables the efficient handling of cargo flows at the port:

We have close communication with Stora Enso to know how much volume is coming to the port. This system has worked for so many years, and everybody knows how to handle it.

Kisch highlighted the fact that while transhipment of cargo from rail to RoRo vessels is operationally efficient, the cost of port operations is extremely high, accounting for $60 \%$ of the company's total shipping cost. Also, Hansen [40] emphasised cost issues for port handling in Gothenburg. From his perspective, Johansson from SOL stated that the frequency of departures of RoRo vessels offers them a competitive advantage in relation to feeder services and lines and facilitates their integration in intermodal transport chains due to the shorter times in port. SOL offers high frequency of departures was also mentioned by Kisch as an important feature of RoRo services that is lacking in container services, as they stay longer in the port.

SECUs stay a maximum of a few days at the port before they are shipped, due to the flexible allocation system with external customers that enables utilisation of excess capacity by third parties. Both interviewees mentioned that each SECU is given a date, based on the cargo unit that has the earliest arrival time in the destination port, and then SECUs are put in lanes with dates. In this way, the right SECU is delivered to the right customer at the right time and place. As Kisch [39] mentioned:

Each box is put in lanes with dates based on the cargo it has and the unit in the box which has the earliest arrival time in the destination port and then given a date to the whole box. This helps us make sure that the right box at the right place, its customer orders in the box and the destination are decided in advance.

He further emphasised that using SECUs enables Stora Enso to transport its cargo efficiently from the mills, which are located inland, reducing the need for warehouses [39]: 
We don't need warehouses, we just produce, load SECUs and ship.

The interviewee added that in Northern Finland, SECUs act as floating warehouses, as sometimes the company needs to produce earlier depending on the client's required delivery time. Another interesting point is that the SECUs are always stripped before they reach the final clients and the goods are reloaded to semitrailers, so the last leg of the transport chain is always by road.

\subsection{The Gothenburg-Zeebrügge RoRo Route}

A major frequent service in Stora Enso's SSS network is the connection between Gothenburg and Zeebrügge. According to Kisch, for trade between Gothenburg and Zeebrügge, Stora Enso charters a couple of vessels from Wagenborg shipping that make two round trips per week. These vessels are purposely built for Stora Enso's cargo backed by a 15-year charter contract [41], with two levels of loading ramps, which reduces the vessels' time at ports and allows them to run at 15 knots, compared to 18-19 knots, which is the sailing speed of their competitors. The forest industry is used to plan for the long duration of its assets, and the long charter time was not internally controversial due to strong volume growth at the time, but might not have been as well received in today's business climate [41].

Bengtsson [44] at France Sped stated that the vessels' lower speed was no real problem to them. The intra-European part-load segment, in which they are mainly active, has a rhythm of collecting by the end of one week and conducting long-distance transport over the weekend; delivery early in the next week allows for slow transport over the weekend. The size of the vessels is 2500 lane metres, and ISO containers on cassettes can be double-stacked. The slow sailing speed in addition to the high load factor of these vessels enhances their sustainable operations and evidence Stora Enso's commitment to sustainability.

Regarding the employment of larger RoRo vessels, Johansson supported that it is neither efficient nor feasible on the Gothenburg-Zeebrügge route despite the reduced unit cost due to economies of scale. Kisch pointed out that larger vessels would increase operating times, as the driving distances on board would be longer, and all cargo would have to wait until the vessel is full. Both interviewees emphasised that frequency of departures is imperative in this route, and it would be difficult to retain it in addition to obtaining high-capacity utilisation of very large vessels. On the Gothenburg-Zeebrügge route, SOL offers five departure per week in both directions [49]. They also stated the infrastructure is a major challenge for the employment of larger vessels.

The interviewee from Stora Enso [39] stated that the Gothenburg-Zeebrügge line has grown significantly over the years, as many companies have changed their production patterns, moving their operations around Gothenburg and increasing their shipments in this line:

... the corridor has grown significantly. We had been working with a lot of companies to change

their production patterns, and Volvo for instance in this respect has increased their production around Gothenburg, and this has led to growth in the shipments.

According to Johansson [43], a modal shift from land-based modes of transport to sea-based has also favoured the use of Gothenburg-Zeebrügge line.

... there were also market changes, a lot of modal shift from road to sea and from rail also...

\section{Discussion and Conclusions}

Due to negative externalities related to unimodal road haulage, the promotion of SSS has been an essential part of the political agenda in the European Union for decades. Regardless of the multiple initiatives undertaken by authorities to increase the usage of SSS, unimodal road haulage still accounts for nearly $50 \%$ of total freight transport by volume in the European Union. The success of the SSS option, to a large extent, is dependent on the seamless integration of individual activities and services offered by different agents or stakeholders involved in a multimodal transport chain. 
In the existing research, the topic of SSS and its integration into the intermodal transport chain has mostly been studied from transport providers' perspective, while the role of a shipper has received little attention. In this paper, through an in-depth case study, the role of a shipper (cargo owner) to integrate multiple traffic modes into a seamless intermodal transport chain and the drivers (enablers) for such integration are explored. Interviews, secondary data and existing literature are the main data sources for this case study.

We found that Stora Enso, a leading forest-products producer, employs an innovative intermodal logistics system for the transport of a huge volume of its products. Instead of relying on third-party logistics providers, Stora Enso has designed a logistics system and purchased rail transport of its cargo from Swedish mills to the Port of Gothenburg and chartered RoRo vessels to cover the long leg of the journeys. By chartering the RoRo vessels, Stora Enso saves capital costs and can release the vessels if an unexpected event, such as a decline in its product demand, occurs. In addition, the usage of the SECU, with the capacity of up to load 80 tons of cargo, reduces total transport and warehousing costs. We believe that these innovative strategies have provided the company with a significant competitive advantage in the market by reducing the per-unit cost of its products and enhancing overall system efficiency.

Stora Enso does not utilise 100\% capacity for its own cargo transport on board the chartered vessels. Thus, to sell extra freight capacity to third parties and manage the operations of its chartered vessels, Stora Enso formed a strategic cooperation with SOL. As a result of this cooperation, in 2017, the utilisation rate on Stora Enso's Gothenburg-Zeebrügge RoRo service route reached 95\% in both directions, although many northbound SECUs are empty. This high load factor is rare for a RoRo service, as SOL sold nearly 100,000 units to third parties and through the use of standby SECUs. Apart from the financial benefits for both Stora Enso and SOL from this cooperation, sustainable transport operations are promoted. The high utilisation rate of the service implies lower greenhouse gas emissions (GHG) emissions per transport unit through improved voyage planning and is in accordance with implementation of the Ship Energy Efficiency Management Plan (SEEMP) [50]. Under the SEEMP, mandatory for all vessels since January 2013, guidance is provided on the way vessels could optimise their operational efficiency performance through technical details, including improved voyage planning, just-in-time arrival of vessels at ports and speed optimisation (MEPC 58/INF.7 2008). In addition, Stora Enso's purpose-built vessels, with two levels of loading ramps that reduce vessels' time in ports and allow them to run at lower speeds, have a high operational efficiency performance that leads to reduced fuel consumption and GHG emissions from their operations, as stated by both López-Navarro [23] and Hjelle [26]. The use of low-sulphur fuel in addition to the low operational speed (15 knots) and the high utilisation rate (95\%) of the RoRo service examined in this study turn it into the greenest transport alternative and enhance the sustainability aspects of RoRo shipping operations.

Although Stora Enso is the charterer of the vessels, priority is usually given to third-party forwarders, which helps sustain these third-party customers. France Sped confirmed that as a small user, it does not see that Stora Enso is prioritised [44]. This finding reflects that by adopting a unique management approach and developing cooperation with SOL, the shipper Stora Enso efficiently transports its own cargo as well as lowers its costs by selling the capacity to third parties on board its RoRo vessels, eventually leading to an increased integration of RoRo into a multimodal transport chain. This is in line with Zachcial [9] and Paixão Casaca and Marlow [4], who emphasised that cooperation amongst transport chain agents and a different management approach are amongst the key drivers for SSS integration into intermodal transport chains.

Moreover, in contrast to Saldanha and Gray [51], who in their Delphi survey found that shippers cannot play any key role in integrating different traffic modes "as a spin-off from serving their own needs", we assert that large shippers are at the centre of a logistics chain, and because of having control of large cargo volumes, they can assist in increasing the integration of multiple traffic modes as illustrated in our case study. In this context, Paixão Casaca and Marlow [19], Ng [33] and Styhre [32] 
corroborate that large cargo volumes ensure higher frequency of a transport service for shippers and increase capacity utilisation of a traffic mode (especially in the RoRo shipping segment), and both these factors are fundamentally important in running an economically feasible RoRo service and facilitating the integration of RoRo services within an intermodal transport chain.

Our findings are consistent with those of Ng, Sauri and Turro [3], who emphasised that high cargo-handling cost in ports is amongst the top barriers to enhancing the integration of RoRo services into intermodal transport chains. In our study, we found that port costs account for nearly $60 \%$ of Stora Enso's total shipment costs. We believe that a reduction in port costs could make intermodal RoRo services cheaper compared to unimodal road haulage and may increase the competitiveness of this mode.

We believe that the results of this paper bring new insights to various actors involved in a transport chain. Ship operators and large shippers might realise the importance of cooperation and shared planning with other agents of a transport chain. Intermodal integration between different traffic modes or strategic collaboration between cargo owners, ship operators and forwarding agents might enhance system efficiency; reduce lead times, emissions and costs; and generate additional revenues for all collaborating parties. Large shippers, especially in the forest industry, may reconsider their logistics and management strategies and may benefit by commencing their own unique transport networks following the case of Stora Enso as presented in this paper.

Based on the findings of this paper, we suggest that to enhance the integration of SSS into intermodal transport chains, policymakers should draft policies considering shippers' needs and encourage innovations in the sector, as innovations may in return reduce unnecessary costs involved (e.g., port costs). In addition, to encourage the use of intermodal transport over unimodal road haulage, behavioural change campaigns targeting all stakeholders of a transport chain should be a part of future policies, as environmental sustainability is dependent not only on technological change, but also on behavioural change.

The major limitations of this research are that the methodology of a case study of shipper-carrier cooperation cannot be considered as representative of transport practices in general, as the carrier operates in Northern Europe, where high sustainability requirements in sea freight transport are applied and the shipper demonstrates a very strong commitment to sustainable transport procurement. The results might be different in other industrial segments or geographical regions of the world. Moreover, although we tried to overcome subjectivity and bias issues and enhance the reliability of our data by conducting semi-structured interviews with various stakeholders involved in the Stora Enso-SOL cooperation, the answers express the personal views and opinions of the interviewees and allow some sort of subjectivity.

The study provides implications for further research. More case studies on instances of shipper-carrier cooperation that have managed to integrate RoRo shipping into intermodal logistics chains could be analysed, giving some insight in other industrial sectors, such as the automotive or steel industry. The case study methodology could also be supplemented with quantitative studies that could further explore the potential development of intermodal RoRo services.

Author Contributions: All authors planned the study and participated in the interviews. A.C. drafted the manuscript. Z.R. provided literature reviews and contributed to the overall suggestions. J.W. reviewed, edited and supervised the manuscript. All authors read and approved the final manuscript.

Funding: The research funding was channelled by the Maritime Competence Centre Lighthouse and the Logistics and Transport Foundation, LTS.

Acknowledgments: The authors thank the interviewees representing Stora Enso and SOL.

Conflicts of Interest: The authors declare no conflict of interest. The funders had no role in the design of the study; in the collection, analyses, or interpretation of data; in the writing of the manuscript; or in the decision to publish the results. 


\section{References}

1. Smith, T.W.P.; Jalkanen, J.P.; Anderson, B.A.; Corbett, J.; Faber, J.; Hanayama, S.; O'Keeffe, E.; Parker, S.; Johansson, L.; Aldous, L.; et al. Third IMO GHG Study 2014; International Maritime Organization (IMO): London, UK, 2014.

2. European Union. EU Transport in Figures, Statistical Pocketbook 2017; Publications Office of the European Union: Luxembourg, 2017.

3. Ng, A.K.Y.; Sauri, S.; Turro, M. Short sea shipping in Europe: Issues, policies and challenges. In Regulating Transport in Europe; Finger, M., Holvad, T., Eds.; Edward Elgar: Cheltenham, UK, 2013; pp. 196-217.

4. Paixão Casaca, A.C.; Marlow, P.B. The competitiveness of short sea shipping in multimodal logistics supply chains: Service attributes. Marit. Policy Manag. 2005, 32, 363-382. [CrossRef]

5. Stopford, M. Maritime Economics, 3rd ed.; Routledge/Taylor and Francis: London, UK, 2009.

6. Caris, A.; Macharis, C.; Janssens, G.K. Decision support in intermodal transport: A new research agenda. Comput. Ind. 2013, 64, 105-112. [CrossRef]

7. Dimić, S.; Pamučar, D.; Ljubojević, S.; Đorović, B. Strategic Transport Management Models-The Case Study of an Oil Industry. Sustainability 2016, 8, 954. [CrossRef]

8. Graham, M.G.; Hughes, D.O. Containerisation in the Eighties; Lloyd's of London Press: London, UK, 1985.

9. Zachcial, M. Short Sea Shipping and Intermodal Transport, OECD/ECMT, Short Sea Shipping in Europe; OECD Publication Services: Paris, France, 2001; pp. 23-38.

10. Cavone, G.; Dotoli, M.; Epicoco, N.; Seatzu, C. Intermodal terminal planning by Petri Nets and Data Envelopment Analysis. Control Eng. Pract. 2017, 69, 9-22. [CrossRef]

11. Gronalt, M.; Schultze, R.-C.; Posset, M. Chapter 5-Intermodal Transport-Basics, Structure, and Planning Approaches. In Sustainable Transportation and Smart Logistics; Faulin, J., Grasman, S.E., Juan, A.A., Hirsch, P., Eds.; Elsevier: Amsterdam, The Netherlands, 2019; pp. 123-149.

12. Crainic, T.G.; Perboli, G.; Rosano, M. Simulation of intermodal freight transportation systems: A taxonomy. Eur. J. Oper. Res. 2018, 270, 401-418. [CrossRef]

13. Kudlac, S.; Gasparik, J.; Dedik, M.; Kurenkov, P.V. Identification of Restricting Criteria for Comprehensive Assessment of Logistics Chains in Intermodal Transport. LOGI Sci. J. Transp. Logist. 2018, 9, 18-27. [CrossRef]

14. Tawfik, C.; Limbourg, S. Pricing Problems in Intermodal Freight Transport: Research Overview and Prospects. Sustainability 2018, 10, 3341. [CrossRef]

15. Blonk, W.A.G. Short Sea Shipping and Inland Waterways as Part of a Sustainable Transportation System. Mar. Pollut. Bull. 1994, 29, 389-392. [CrossRef]

16. Buxton, I.L.; Daggitt, R.P.; King, J. Cargo Access Equipment for Merchant Ships; E. \& F.N. Spon Limited: London, UK, 1978.

17. Medda, F.; Trujillo, L. Short-sea shipping: An analysis of its determinants. Marit. Policy Manag. 2010, 37, 285-303. [CrossRef]

18. Douet, M.; Cappuccilli, J.F. A review of Short Sea Shipping policy in the European Union. J. Transp. Geogr. 2011, 19, 968-976. [CrossRef]

19. Casaca, A.C.P.; Marlow, P.B. The impact of the trans-European transport networks on the development of short sea shipping. Marit. Econ. Logist. 2007, 9, 302-323. [CrossRef]

20. Maksimavicius, R. Some elements of the ro-ro terminals. Transport 2004, 19, 75-81. [CrossRef]

21. Brooks, M.R.; Frost, J.D. Short sea shipping: A Canadian perspective. Marit. Policy Manag. 2004, 31, $393-407$. [CrossRef]

22. Konstantinus, A.; Zuidgeest, M.; Christodoulou, A.; Raza, Z.; Woxenius, J. Barriers and Enablers for Short Sea Shipping in the Southern African Development Community. Sustainability 2019, 11, 1532. [CrossRef]

23. López-Navarro, M.Á. Environmental Factors and Intermodal Freight Transportation: Analysis of the Decision Bases in the Case of Spanish Motorways of the Sea. Sustainability 2014, 6, 1544. [CrossRef]

24. Paixão, A.C.; Marlow, P.B. Strengths and weaknesses of short sea shipping. Mar. Policy 2002, 26, 167-178. [CrossRef]

25. European Union. EU Transport in Figures, Statistical Pocketbook 2018; Publications Office of the European Union: Luxembourg, 2018.

26. Hjelle, H.M. Short Sea Shipping's Green Label at Risk. Transp. Rev. 2010, 30, 617-640. [CrossRef] 
27. European Sea Port Organisation (ESPO). ESPO Annual Report 2006-2007; European Sea Port Organisation: Brussels, Belgium, 2007.

28. Eurostat. Maritime Transport Statistics-Short Sea Shipping of Goods. Available online: http://ec.europa.eu/eurostat/statistics-explained/index.php/Maritime_transport_statistics_-_short_s ea_shipping_of_goods\#Short_sea_shipping_by_type_of_cargo (accessed on 16 March 2018).

29. Paixão Casaca, A.C.; Marlow, P.B. Logistics strategies for short sea shipping operating as part of multimodal transport chains. Marit. Policy Manag. 2009, 36, 1-19. [CrossRef]

30. López-Navarro, M.Á.; Ángel Moliner, M.; María Rodríguez, R.; Sánchez, J. Accompanied versus Unaccompanied Transport in Short Sea Shipping between Spain and Italy: An Analysis from Transport Road Firms Perspective. Transp. Rev. 2011, 31, 425-444. [CrossRef]

31. Lopez-Navarro, M.A. Unaccompanied transport as a strategy for international road hauliers in Ro-Ro short sea shipping. Marit. Econ. Logist. 2013, 15, 374-394. [CrossRef]

32. Styhre, L. Strategies for capacity utilisation in short sea shipping. Marit. Econ. Logist. 2009, 11, $418-437$. [CrossRef]

33. Ng, A.K.Y. Competitiveness of short sea shipping and the role of port: The case of North Europe. Marit. Policy Manag. 2009, 36, 337-352. [CrossRef]

34. Swedish Forest Industries Federation. Facts E Figures; Swedish Forest Industries Federation: Stockholm, Sweden, 2016.

35. Port of Gothenburg. The Largest Forest Port in Sweden. Available online: https://www.portofgothenburg.c om/forestport/the-largest-forest-port-in-sweden/ (accessed on 4 April 2018).

36. Voss, C.; Tsikriktsis, N.; Frohlich, M. Case research in operations management. Int. J. Oper. Prod. Manag. 2002, 22, 195-219. [CrossRef]

37. Yin, R.K. Case Study Research: Design and Methods, 4th ed.; Sage: Thousand Oaks, CA, USA, 2009.

38. Eisenhardt, K.M. Building Theories from Case Study Research. Acad. Manag. Rev. 1989, 14, 532-550. [CrossRef]

39. Kisch, K. Manager of European Shipping Services, Stora Enso, Christodoulou, A., Raza, Z., Woxenius, J., Interviewed. 8 February 2018.

40. Hansen, K. Senior Vice President Stora Enso \& CEO of Stora Enso Logistics AB, Woxenius, J., Gonzalez-Aregall, M., Santén, V., Interviewed. 8 May 2018.

41. Wiklund, S. Former Vice President Business Development and Acting CEO of Stora Enso Logistics AB, Woxenius, J., Interviewed. 8 May 2018.

42. Kappelin, H. Network Design E Transport Analyst, Stora Enso, Christodoulou, A., Interviewed. 12 February 2019.

43. Johansson, R. CEO Swedish Orient Line, SOL, Christodoulou, A., Raza, Z., Woxenius, J., Interviewed. 6 March 2018.

44. Bengtsson, K. CEO of France Sped AB, Woxenius, J., Interviewed. 1 February 2019.

45. Stora Enso. Stora Enso's 2018 Full Year Financial Results; Stora Enso: Helsinki, Finland, 2019.

46. Stora Enso. Stora Enso's Annual Report 2016; Stora Enso: Helsinki, Finland, 2017.

47. Georgopoulou, C.; Kakalis, N.M.P.; Recagno, V.; Fozza, S. Benchmarking the SuperGreen Corridors with Green Technologies. In Green Transportation Logistics; International Series in Operations Research \& Management Science; Psaraftis, H.N., Ed.; Springer: Cham, Switzerland, 2016; Volume 226.

48. Udikas, M. Stora Enso byter Hamn-Göteborg Tappar 1.5 miljoner ton (Stora Enso Changes Ports-Gothenburg Loses 1.5 million tons). Transport-Nytt, 18 November 2014.

49. SOL Lines. Timetable Gothenburg-Zeebrügge. Available online: https://www.sollines.se/en/sol-continent-1 ine/route-network/gothenburg-zeebrugge (accessed on 6 February 2019).

50. IMO. Energy Efficiency Measures. Available online: http://www.imo.org/en/ourwork/environment/pollution prevention/airpollution/pages/technical-and-operational-measures.aspx (accessed on 18 December 2018).

51. Saldanha, J.; Gray, R. The potential for British coastal shipping in a multimodal chain. Marit. Policy Manag. 2002, 29, 77-92. [CrossRef]

(C) 2019 by the authors. Licensee MDPI, Basel, Switzerland. This article is an open access article distributed under the terms and conditions of the Creative Commons Attribution (CC BY) license (http://creativecommons.org/licenses/by/4.0/). 